\title{
Integrating E-Learning Technologies in Business Education Course Delivery During Covid-19 Lockdown in South-South Nigeria
}

\author{
Pac Ordu $^{1^{*}} \quad$ Musa A. Abdulkarim ${ }^{2}$ \\ 1.Department of Business Education, Federal University Otuoke, PMB 26 126, Yenagoa, Nigeria \\ 2.School of Business Education, Federal College of Education (Technical) Omoku, PMB 11, Omoku, Rivers \\ State, Nigeria
}

\begin{abstract}
This study investigates the acceptability of utilizing e-learning technologies for business education course-delivery during the period of tertiary institutions lockdown as a result of COVID-19 pandemic in south-south, Nigeria. Hinged on the theory of Technology Acceptance by Davis, F. D, a descriptive survey research design using quantitative and qualitative approach was adopted. Data was collected via questionnaire, and Focus Group Discussion (FGD) was used for the qualitative approach. The study revealed that business educators utilized elearning technologies to a very low extent during the pandemic. Therefore, strategies to forestall such hindrances and difficulties were identified and discussed.
\end{abstract}

Keywords: e-learning, academic staff attitudes, ICT, synchronous, asynchronous, COVID-19

DOI: $10.7176 / \mathrm{JEP} / 11-32-09$

Publication date: November $30^{\text {th }} 2020$

\section{Introduction}

In the past two decades, technological offerings have been penetrating the Nigerian education system especially at the tertiary institution level. Many educational programmes such as: Business education have the provision of computer laboratory, intranet, internet access and basic laboratory equipment such as: multimedia projectors, interactive board, video conferring tools as basic requirements for accreditation by the three supervisory agencies of tertiary institutions in Nigeria (National Commission for Colleges of Education, NCCE, 2012, National Board for Technical Education, NBTE, 2014, National University Commission, 2018, Author, 2019). These requirements were meant to reposition Business education programme to prepare recipients in line with the global technological trends so that the graduates can become technology savvy in response to the demand of 21 st century workplace

Nevertheless, it is important to note that the integration and utilization of any technological offerings in any educational programme, Business education inclusive is dependent on several factors. According to Anderson and Ainley (2010), one of the basic conditions for utilizing technological tools in delivering curriculum content is access to the required technological tools. Also, Ayim (2018) noted another condition for active utilization of technological product or services in education as competency and expertise of users in utilizing the technological tools and resources. Supporting this, Abah (2019) opined that in assessing the utilization of technology to drive task performance in education, the issue of access and skills remain primordial condition for the use. Access to and skills of the users remain significant because as noted by Odiachi (2019), the utilization of technology in teaching and learning focuses on how educators can achieve the goals of education with the aid of technology.

There are many technologies viewed from the perspective of information and communication technologies that have been deployed for utilization in business education programme in Nigeria. According to Ebisine (2011) ICTs integrated in the teaching and learning of business education include: computers, internet, global system of communication (GSM), world-wide web (www), teleconferencing and video-conferencing devices, smart board, search engines, goggle, blogs, Podcasts, social networks tools, e-library and multimedia projectors. Nwosu and Ojo (2014) opined that ICT deployed in business education include but not limited to: internet, computers, interactive multimedia systems, and digital telecommunication devices. Amiaya (2014) also opined that ICTs deployed in business education include: computers, internet and intranet, general system of mobile communication (GSM), worldwide web (www), teleconferencing and video-conferencing devices, social media, interactive white board and mobile technologies. These various technologies deployed in business education programme can be conveniently categorized as either Distributive Technologies (DT) or Interactive Technologies (IT). Njamanze (2011) gave a clear distinction of what constitute distributive technologies from interactive technologies. According to the author, distributive technologies only support the broadcasting of learning materials in a particular way that does not support interaction between the teacher and the learner; while interactive technologies support communication between the teacher and the learner.

Interactive Technologies (IT) includes both synchronous and asynchronous technologies. According to Bastable, Gramet, Jacobs, and Sopczyk (2010) noted that IT includes both synchronous technologies that allow all users to interact on real-time basis and asynchronous technologies that allow users to work at their own convenient 
time. Supporting this, Njamanze (2011) noted that synchronous technologies allow all learners to engage in learning activity at the same time, using the technology such as: video conferencing, audio conferencing or interactive television to bridge their spatial separation; while asynchronous technologies allow learners to communicate with time delays between massages, as well as bridges the barrier of time and space in communication. Odili (2016) noted that synchronous IT supports real-time interaction between the educator and the learners and asynchronous IT support the learners learning at their own time especially with the advancement in computer technology and emergence of the internet. It is important to note that access to both synchronous and asynchronous technologies empowers educators to drive electronic learning (e-learning).

E-learning promoted through the use of synchronous and asynchronous technologies can take different nature. According to Ifijeh, Iwu-James and Adebayo (2016), e-learning can start with partial and supplementary use of technological offerings such as: computers, networks, software, internet, wireless, and mobile technologies in classroom to deliver course contents and facilitate teacher, student and administrator interaction in educational programmes. Nwagwu and Azih (2016) opined that e-learning as an aspect of Information and Communication Technology (ICT) has to do with preparing and delivery educational programme through the utilization of computer aided resources such as: as e-mail, text messaging, online chats, web pages, YouTube, audio and video conferencing etc. Nawaz and Kundi (2010) opined that a variety of concepts such as: computer-based instruction, computer-assisted instruction, web-based learning, distance education, online instruction, multimedia instruction and networked learning and electronic learning are used interchangeably to represent e-learning.

Of these concepts, web-based learning, distance education, online instruction, multimedia instruction (using CD, DVD, and YouTube videos to provide instructions), and networked learning eliminates the barrier of time, place and space for instruction. Hence, can be utilized to substitute traditional classroom or lecture hall learning situations during the period of crises when learners are physical dispersed from school environment. Supporting this, Nawaz and Kundi (2010) noted that e-learning technologies provide students who have access to datanetworks such as: internet, intranet and extranet with the opportunity to continue learning through online synchronous and asynchronous virtual learning environments when they are physically dispersed as a result of certain environmental or unforeseen disasters. Inije and Utoware (2013) also opined that e-learning can be promoted through the use of internet; intranet, CD - ROM, Digital Video Disc (DVD) and YouTube videos to provide learning materials to students to learn at their own convenient time outside the school environment.

Many researchers have examined one aspect of e-learning or the other in south-south, Nigeria. For instance, Inije and Utoware (2013) assessed the utilization of e-learning technologies in Business education instructional delivery in Colleges of Education in Delta State, Nigeria and discovered that e-learning technology resources such as: e-lectures, personal computers, internet and web browsers, video conferencing were not extensively utilized in teaching business education in the colleges of education due to many challenges which include shortage of qualified staff with e-learning application, lack of e-learning facilities, epileptic power supply and poor state of elearning infrastructure in the colleges of education. Babalola, Dambo and Bupo (2019) determined the extent of utilization of online platform for e-learning by Business education postgraduates' students in universities in southsouth, Nigeria and the study revealed a low extent of utilization. Elogbo and Akek (2019) conducted study to access the extent of utilization of world wide web and e-mail in instructional delivery of business education in Federal universities in south-south, Nigeria and the study revealed that to a great extent world wide web and email are being utilized by lecturers in teaching of Business education courses.

\section{Statement of the Problem}

Despite access to data-networks such as: internet, smart technologies such as: computers, iPads, android phones, DVD players and video conferencing technologies by both Business education teachers and students, instructions on business education courses like many educational programmes ceased with the closure of tertiary institutions in south-south, Nigeria during the period of COVID-19. This is because every Nigerian Business education student and academic within this zone were confined to their home and neighbourhood from the second week of Covid19 pandemic, when governments (Federal and States) ordered the closure of all secondary schools and tertiary institutions across the country to curtail the spread of the virus. However, within same period players in the private sector developed various coping mechanism such as work from home utilizing same technologies that can be used for e-learning such as: video conferencing platforms, social media and other online platforms (Alugbin, 2020), this act kept their business going on, but that cannot be said of the education system which was totally halted as many classes and programmes could not continue operating remotely using synchronous and asynchronous technologies that support e-learning. This calls to questioning the acceptability of utilizing e-learning technologies amongst educators and students especially Business educators and students who are collaborating for the purpose of providing the future manpower needs of the private sector driven by technological tools.

\section{Purpose of the study}

The main purpose of this study is to investigate the acceptability of utilization of e-learning technologies to deliver 
business education courses during the period of tertiary institutions shut down as a result of covid-19 in southsouth, Nigeria. Specifically, the study seeks to:

1) determine the extent to which business educators believed that e-learning technologies are useful for delivering business education courses when learners are dispersed.

2) determine the extent to which business educators can utilize e-learning technologies to deliver business education courses when learners are dispersed.

3) determine the extent to which business educators utilized e-learning technologies to deliver business education courses when learners are dispersed.

4) determine the factors that hindered business educators from utilizing e-learning technologies to deliver business education courses when learners are dispersed.

\section{Research Questions}

The following research questions guided the study:

1) To what extent do business educators believed that e-learning technologies are useful for delivering business education courses when learners are dispersed?

2) To what extent can business educators utilize e-learning technologies to deliver business education courses when learners are dispersed?

3) To what extent did business educators utilize e-learning technologies to deliver business education courses when learners are dispersed?

4) What are the factors that hindered business educators from utilizing e-learning technologies to deliver business education courses when learners are dispersed?

\section{Theoretical Review}

\subsection{Technology Acceptance Theory by Davis, F. D. (1989)}

This study is based on the technology acceptance theory by Davis (1989) which states that the perceived usefulness and ease of utilizing certain technology have higher impact on the acceptance of the technology to improve one's performance at work. The theory therefore is based on two constructs: "perceived usefulness" of the technology and the "perceived ease of using" the technology tools to perform the required job. The perceived usefulness was defined by Davis as "the degree in which a person believes that using a particular technology would enhance his or performance at work". The author defined perceived ease of utilization as "the degree in which a person believes that he/she can use a particular technology without much effort". The model for technology acceptance was based on planned behaviour of using technologies as tools for ensuring the performance of tasks (see Figure 1).

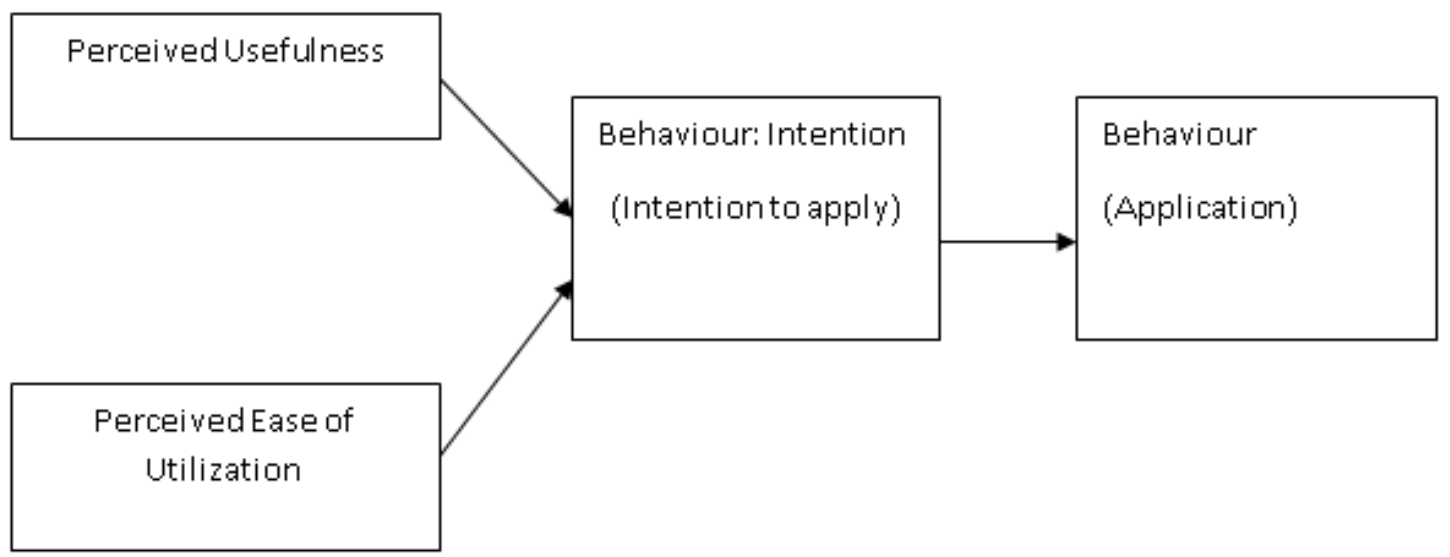

Figure 1. Technology Acceptance Model Source: Davis (1989)

Figure 1 above shows that the utilization of any technology is subject to the user's perceived usefulness and the perceived ease of utilizing the technology to perform his/her work. The diagram shows that the users whose perceptions are positive develop the intention to use the technology and the greater the intention the better the chances of applying the technology to work. Thus, the perceived usefulness and perceived ease of use help the user of technology to form the intention to use and the intention subsequently drives the usage. This theory is of significant to present study because it shows that the factors to be assessed when determining the acceptability to utilize any given technology to perform any act are: perceived usefulness and perceived ease of use. Hence, in this study the researchers assumed that business educators perceived usefulness of e-learning technologies and perceived ease of use should lead to their actual utilization of e-learning technology during period when student 
are physically dispersed.

\section{Methods}

This study adopted a descriptive survey research design using both quantitative and qualitative research approaches. The population of the study was made up of 134 Business educators who were active member of south-south/southeast Association of Business Education of Nigeria WhatsApp group. Purposive sampling technique was used to select 56 Business educators for the study on the basis that they are lecturers in any of the south-south, tertiary institutions. However, only 16 out of the 56 were used for the Focus Group Discussion aimed at collecting qualitative responses. Researchers' designed questionnaire was titled "Acceptability of Utilization of E-Learning Technologies for Delivery Business Education Courses in Crisis Period Questionnaire (AUELTDBECCPQ)" was used for the purpose of collecting quantitative data.

The questionnaire contains meant to elicit responses to answer research question 1 to 3 ; while research question 4 was used to form two interview questions aimed at collecting responses from Focus Group Discussion (FGD) on south-south, Nigeria Business Educators' WhatsApp social media platform. The FGD lasted for one hour on the platform and at the end members of the WhatsApp were thanked for their personal opinion relating to topics posed. The questionnaire was subjected to reliability of internal consistency using Cronbach alpha with data collected from 10 business educators who were not part of the sample of the study. The computation gave a reliability index of 0.76 . Mean and cluster mean scores were used for the quantitative data analysis and the opinion of all the Business educators who respondents during the discussion were summarized for the qualitative responses. For decision making on quantitative analysis, the following were used as guide: Mean of 3.0 above will be regarded as Very High Extent, 2.0 to 2.99 will be regarded as High Extent, 1.5 to 1.99 will be regarded as Low Extent and below 1.5 will be regarded as Very Low Extent.

\section{Results/Discussion}

Research Questions 1: To what extent does business educators believed that e-learning technologies are useful for delivering business education courses when learners are dispersed?

Table 1. Summary of Mean Value on the Extent to which business educators believed that e-learning technologies are useful for delivering business education when learners are dispersed. $n=134$

\begin{tabular}{rlccc}
\hline S/N & Availability Items & $\mathbf{X}$ & SD & Decision \\
\hline 1 & Computer & 2.77 & 0.66 & HE \\
2 & Internet & 3.02 & 1.00 & VHE \\
3 & Video conferencing & 2.71 & 0.75 & HE \\
4 & Video books & 2.75 & 0.71 & HE \\
5 & YouTube & 3.06 & 0.83 & VHE \\
6 & Blogs/Online Journaling & 3.03 & 1.07 & VHE \\
7 & Twitter & 2.86 & 0.75 & HE \\
8 & Instagram & 2.95 & 0.83 & HE \\
9 & Smart phones & 3.06 & 0.95 & VHE \\
10 & Audio conferencing & 2.99 & 0.96 & HE \\
11 & e-mail & 3.10 & 1.00 & VHE \\
12 & CD ROM & 3.11 & 0.94 & VHE \\
13 & DVD plate & 3.13 & 0.92 & VHE \\
14 & Zoom meetings & 2.80 & 0.95 & HE \\
15 & WhatsApp group chart & 2.93 & 0.93 & HE
\end{tabular}

Table 1 shows that the respondents are of the opinion that internet, YouTube, blogs/online journaling, smart phones, e-mail, CD ROM, and DVD plate are to a very high extent useful for delivering business education courses when learners are dispersed with mean scores of 3.02, 3.06, 3.03, 3.06, 3.10, 3.11, and 3.13 respectively. The respondents are also of the opinion that computer, video conferencing, video books, Twitter, Instagram, audio conferencing, zoom meetings, and WhatsApp group chart are to a high extent useful in delivering business education courses when learners are dispersed with mean scores of 2.77, 2.71, 2.75, 2.86, 2.95, 2.99, 2.80, and 2.93 respectively. However, when the cluster mean score of 2.95 is taken into consideration, it can be concluded that e-learning technologies assessed in this study are to a high extent useful in delivering business education courses when learners are dispersed.

Research Questions 2: To what extent can business educators utilize e-learning technologies to deliver business education courses when learners are dispersed? 
Table 2. Summary of Mean Value on the Extent to which business educators can utilize e-learning technologies to deliver business education courses to dispersed learners. $n=134$

\begin{tabular}{rlccc}
\hline S/N & Availability Items & $\mathbf{X}$ & SD & Decision \\
\hline & I can deliver/broadcast business education courses to & & & \\
& dispersed learners with & & & \\
1 & Computer & 3.16 & 0.89 & VHE \\
2 & Internet & 3.30 & 0.67 & VHE \\
3 & Video conferencing & 2.90 & 0.74 & HE \\
4 & Video books & 2.58 & 0.80 & HE \\
5 & YouTube & 2.57 & 0.75 & HE \\
6 & Blogs/Online Journaling & 2.37 & 1.01 & HE \\
7 & Twitter & 2.19 & 1.24 & HE \\
8 & Instagram & 2.22 & 1.09 & HE \\
9 & Smart phones & 3.31 & 0.84 & VHE \\
10 & Audio conferencing & 2.19 & 1.21 & HE \\
11 & e-mail & 3.45 & 0.91 & VHE \\
12 & CD ROM & 3.49 & 0.80 & VHE \\
13 & DVD plate & 3.19 & 0.96 & VHE \\
14 & Zoom meetings & 1.98 & 1.11 & LE \\
15 & WhatsApp group chart & 3.19 & 0.88 & VHE \\
& Cluster mean & 2.81 & 0.73 & HE \\
\hline
\end{tabular}

Table 2 shows that the respondents are of the opinion that they can deliver/broadcast business education courses to dispersed learners to a very high extent with computer, internet, smart phones, email, CD ROM, DVD and WhatsApp group chart with mean scores of 3.16, 3.30, 3.31, 3.45, 3.49, 3.19, and 3.19 respectively. The respondents are also of the opinion that to a high extent they can deliver/broadcast business education courses to dispersed learners with video conferencing, video books, blogs/online journaling, twitter, Instagram, and audio conferencing, with mean scores of 2.90, 2.58, 2.57, 2.37, 2.19, 2.22, and 2.19 respectively. The respondents are also of the opinion that they can to a low extent deliver/broadcast business education courses to dispersed learners with zoom meetings with a mean score of 1.98 . However, when the cluster mean score of 2.81 is considered, it can be concluded that business educators can use e-learning technologies assessed in this study to a high extent to deliver/broadcast business education courses to dispersed learners.

Research Questions 3: To what extent did business educators utilize e-learning technologies to deliver business education courses to dispersed learners during COVID-19?

Table 3. Summary of Mean Value on the Extent to which business educators utilize e-learning technologies to deliver business education courses to dispersed learners during COVID-19. $n=134$

\begin{tabular}{|c|c|c|c|c|}
\hline $\mathbf{S} / \mathbf{N}$ & Availability Items & $\mathbf{X}$ & SD & Decision \\
\hline & $\begin{array}{l}\text { During COVID-19 lockdown, I delivered/broadcast } \\
\text { business education courses to dispersed learners with }\end{array}$ & & & \\
\hline 1 & Computer & 1.46 & 0.87 & VLE \\
\hline 2 & Internet & 1.42 & 0.83 & VLE \\
\hline 3 & Video conferencing & 1.22 & 0.61 & VLE \\
\hline 4 & Video books & 1.31 & 0.73 & VLE \\
\hline 5 & YouTube & 1.34 & 0.84 & VLE \\
\hline 6 & Blogs/Online Journaling & 1.40 & 0.87 & VLE \\
\hline 7 & Twitter & 1.46 & 0.97 & VLE \\
\hline 8 & Instagram & 1.34 & 0.84 & VLE \\
\hline 9 & Smart phones & 1.25 & 0.72 & VLE \\
\hline 10 & Audio conferencing & 1.34 & 0.84 & VLE \\
\hline 11 & e-mail & 1.29 & 0.86 & VLE \\
\hline 12 & CD ROM & 1.42 & 0.94 & VLE \\
\hline 13 & DVD plate & 1.18 & 0.57 & VLE \\
\hline 14 & Zoom meetings & 1.27 & 0.78 & VLE \\
\hline \multirow[t]{2}{*}{15} & WhatsApp group chart & 1.48 & 0.94 & VLE \\
\hline & Cluster mean & 1.35 & 0.81 & VLE \\
\hline
\end{tabular}

Table 3 shows that the respondents are of the opinion that during COVID-19 lockdown, they to a very low extent delivered/broadcast business education courses to dispersed learners with computer, internet, video conferencing, video books, YouTube, blogs/online journaling, twitter, Instagram, smart phones, audio conferencing, e-mail, CD ROM, DVD plate, zoom meetings and WhatsApp group chart. In same vein, when the 
cluster mean score of 1.35 is considered, it can be concluded that Business educators in south-south, Nigeria utilized e-learning technologies to deliver/broadcast business education courses at a very low extent rate during COVID-19 lockdown.

Research Questions 4: What are the factors that hindered business educators from utilizing e-learning technologies to deliver business education courses to dispersed learners during COVID-19 lockdown?

Table 4. Summary of Major Points from Focus Group Discussion on the factors that hindered business educations in south-south, Nigeria from utilizing e-learning technologies to deliver business education courses to dispersed learners during COVID-19 lockdown

\section{$\mathbf{S} / \mathbf{N}$ Factors}

1 Lack of access to subsidized computers/smart phones

2 Poor internet networks

3 Epileptic power supply

4 Lack of legal support for the use of e-learning technologies to delivery courses to dispersed learners

5 Issues of quality electronic course content development

6 Technological divide amongst business educators and business education students

Lack of mana

\section{Discussion of Findings}

The finding relating to specific purpose one shows that business educators are of the opinion that e-learning technologies assessed in this study are to a high extent useful in delivering business education courses when learners are dispersed. This finding emanated from the fact that most of the business educators from south-south, Nigeria assessed are of the opinion that internet, YouTube, blogs/online journaling, smart phones, e-mail, CD ROM, and DVD plate are to a very high extent useful for delivering business education courses when learners are dispersed; while computer, video conferencing, video books, Twitter, Instagram, audio conferencing, zoom meetings, and WhatsApp group chart are to a high extent useful in delivering business education courses when learners are dispersed. The finding of this study is supported by the position held by Inije and Utoware (2013) when they noted that internet; intranet, CD - ROM, Digital Video Disc (DVD) and YouTube videos are useful for providing learning materials to students to learn at their own convenient time outside the school environment.

The finding relating to specific purpose two shows that business educators are of the opinion that they can use e-learning technologies assessed in this study to a high extent to deliver/broadcast business education courses to dispersed learners. The finding emanated from the fact that the respondents are of the opinion that they can deliver/broadcast business education courses to dispersed learners to a very high extent with computer, internet, smart phones, email, CD ROM, DVD and WhatsApp; while they can also deliver/broadcast business education courses to dispersed learners with video conferencing, video books, blogs/online journaling, twitter, Instagram, and audio conferencing.

The finding relating to specific purpose three shows that business educators in south-south, Nigeria are of the opinion that they to a very low extent utilized e-learning technologies to deliver/broadcast business education courses during COVID-19 lockdown. This finding emanated from the fact that the respondents opined that they to a very low extent delivered/broadcast business education courses to dispersed learners with computer, internet, video conferencing, video books, YouTube, blogs/online journaling, twitter, Instagram, smart phones, audio conferencing, e-mail, CD ROM, DVD plate, zoom meetings and WhatsApp group chart during the COVID-19 lockdown. This finding is supported by the findings of Inije and Utoware (2013) when they discovered that elearning technology resources such as: e-lectures, personal computers, internet and web browsers, video conferencing were not extensively utilized in teaching business education. The finding is also supported by the discovery of Babalola, Dambo and Bupo (2019) their study revealed a low extent of utilization of online platform for e-learning by Business education postgraduates' students in universities in south-south, Nigeria. It is worth noting that the supporting study was limited to online e-learning technologies but the present study covers but online and offline e-learning technologies.

The findings of the study also revealed the factors that hindered the utilization of e-learning technologies to deliver business education courses to dispersed learners during COVID-19 lockdown are: lack of access to subsidized computers/smart phones, poor internet networks, epileptic power supply, lack of legal support for the use of e-learning technologies to deliver courses to dispersed learners, issues of quality control of e-content development, technological divide amongst business educators and students, and lack of management support. These findings are in conformity with Inije and Utoware (2013) discovery that the utilization of e-learning technologies is hindered by lack of e-learning facilities, epileptic electricity supply and poor infrastructure needed to support e-learning. 


\section{Conclusion(s)}

Based on the findings of this study, it can be concluded that delivering business education courses to dispersed learners during crisis and pandemic period that would necessitate the closure of institutions such as the present COVID-19 period may not possible in south-south, Nigeria. The impossibility of this action is not caused by the negative view of business educators about the usefulness e-learning technologies to achieve such purpose or their inability to use such technologies to drive such objective but rather by legal, political and administrative factors. These legal, political and administrative factors are crucial to empowering both business educators and their students to engage in such distance learning adventure where circumstances beyond human control hinder them from utilizing normal school settings. Therefore, if Nigerian business educators from south-south must be empowered to deliver business education courses to dispersed learners during tertiary institution lockdown as experienced presently, these problems must be solved.

\section{Recommendations}

Based on the findings and conclusions drawn, the following recommendations are put forward for implementation:

1) Federal and State government in Nigeria should promote the policy of one student - one laptop and one teacher - one laptop through subsidized sales at the point of admission so that both business educators and their students can be empowered utilize such technology to learn at any time and at anywhere.

2) Association of Business Educators of Nigeria (ABEN) should promote a bill through the national and state assemblies to provide legal framework for course delivery using e-learning technologies to dispersed learners during crises and pandemic. The bill should be tagged "A Bill to Complement Normal Classroom Course Delivery with e-Learning Technologies to Dispersed Learners during Crisis".

3) Train-the-trainer workshops should be organized for all business educators on how to develop electronic course content, use blog/online journaling, and use other e-learning technologies to facilitate course delivery to dispersed learners.

4) Federal ministry of education and her states counterpart should make case for improved broadband networks to support online learning to dispersed learners during crisis and lockdowns.

5) E-learning technologies such as: CD ROM, DVD plates and flash devices should be used to record quality lectures on business education courses by business educators and made available to business education students at the beginning of semesters at subsidized rate to enable them continue learning in case of crisis leading to school lockdown.

\section{References}

Abah, J. (2019). Theoretical and conceptual framework for digital inclusion among mathematics education students in Nigeria. Global Perspectives on Educational Issues, 79-111.

Amiaya, A. O. (2014). Integrating new technologies into office technology and management curriculum: challenges and strategies. Business Education Journal, 1(2), 101-113.

Anderson, R., \& Ainley, J. (2010). Technology and learning: Access in schools around the world (3rd ed.). (E. B. B. McGaw, Ed.). Elsevier.

Anyim, W. O. (2018). Assessment of ICT literacy skills of digital library users and staff in Salem University Lokoja, Kogi. Library Philosophy and Practice.

Babalola, J. O., Dambo, B. I., \& Bupo, G. O. (2019). Utilization of online platforms for e-learning by Business education postgraduate students in universities in south-south, Nigeria. Nigerian Journal of Business Education, 6(1), 182-197.

Davis, F. D. (1989). Perceived usefulness, perceived ease of use and user acceptance of information technology. MIS Quarterly, 13(3), 319-339.

Ebisine, S. E. (2011). ICT and mathematics teaching: A look at the challenges. The International conference on ICT and educational development in Africa, Abraka.

Elogbo, E. E., \& Akek, M. N. (2019). Extent of utilization of world wide web and e-mail in instructional delivery of Business education in federal universities in south-south, Nigeria. Nigerian Journal of Business Education, $6(1), 217-228$.

Inije, G. O., \& Utoware, J. D. (2013). Utilization of e-learning technologies in Business Education instructional delivery in Colleges of Education in Delta State, Nigeria. International Journal of Education and Research, $1(10), 1-14$.

National Board for Technical Education. (2008). Web technology: National diploma in computer science, Kaduna. UNESCO-Nigeria.

National Commission for Colleges of Education. (2012). Nigeria certificate in education minimum standards for vocational and technical education. National Commission for Colleges of Education.

National University Commission. (2015). Administration and Management. National University Commission.

Nawaz, A., \& Kundi, G. M. (2010). Digital literacy: an analysis of contemporary paradigms. Journal of Science 
and Technology Education Research, 1(2), 19-29. http://www.academicjournals.org/JSTE

Njamanze, Q. U. (2011). ICT in participatory development of teaching/learning English as a global language in Nigeria: A discourse. African Journal of Teacher Education, 1(1). https://doi.org/10.21083/ajote.v1i1.1584

Nwagwu, L., \& Azih, N. (2016). Status of technologies in business education departments of tertiary institutions in Ebonyi State for effective integration of electronic learning. British Journal of Education, 4(4), 49-59.

Nwosu, B. O., \& Ojo, K. E. (2014). Improving business education and industry collaboration for manpower training in the era of new technologies. Nigerian Journal of Business Education, 2(1), 1-9.

Odiachi, B. (2019). Availability and utilization of e-learning resources for teaching and learning of office technology and management course in polytechnics in Delta State. Association of Business Educators in Nigeria (ABEN), 6, pp. 661-671.

Ordu, P., \& Abdulkarim, M. (2019). Empirical evidence on the influence of experiential instructional design learning activities on business education students' e-business competency development. European Journal of Education Studies, 6(5), 73-86

Orike, K. U., I., I., \& Okereke, G. O. (2017). Competency of business education students in information communication technology (ICT) for learning in tertiary institutions in Rivers state. International Journal of Advanced Academic Research, 3(6), 1-11.

Utoware, J. D., \& Kren-Ikidi, P. C. (2013). New technologies in business education for instruction and practice: imperatives for quality assurance. International Journal of Contemporary Research, 3(9), 124-130.

Utoware, J. D., Kren-Ikidi, C. P., \& Apreala, I. O. (2016). Issues and trends in the application of new technologies in teaching business education in Nigerian universities in south-south States. Nigerian Journal of Business Education, 3(2), 52-63. 